\title{
PERANAN PATOLOGI DALAM DIAGNOSTIK TUMOR PAYUDARA
}

\author{
Noza Hilbertina
}

Bagian Patologi Anatomi Fakultas Kedokteran Universitas Andalas Padang

\section{Pendahuluan}

Tumor payudara merupakan salah satu lesi yang paling sering dijumpai sehari-hari dan kanker payudara merupakan kanker paling sering ditemukan pada wanita dinegara Barat. ${ }^{1}$ Di Indonesia, kanker payudara menempati urutan teratas diikuti dengan kanker leher rahim. Insiden kanker payudara pada negara berkembang meningkat lebih cepat dibandingkan negara maju dan kanker payudara pada negara ini berasosiasi dengan ketahanan yang lebih buruk . ${ }^{1}$ Kanker payudara merupakan penyebab utama morbiditas dan mortalitas di Amerika Serikat dimana terdapat 192.200 kasus baru dan 40.020 kematian pada tahun 2001. ${ }^{2}$

Dari seluruh kematian kanker akibat kanker payudara di dunia pada tahun 2002, lebih $50 \%$ nya terjadi dinegara dengan sumber daya terbatas. Keadaan ini disebabkan karena stadium penyakit yang telah lanjut, serta keterbatasan sarana diagnostik dan terapeutik pada negara tersebut. ${ }^{1}$

Untuk memperbaiki luaran kanker payudara penting untuk meningkatkan kewaspadaan terhadap kanker payudara, mengenali kanker secara akurat terutama pada stadium dini karena diagnosis yang dini dapat menyelamatkan kehidupan, menghemat biaya dan mengurangi terapi yang agresif. $^{1}$

\section{Patologi dalam Diagnostik Tumor Payudara}

Benjolan payudara dapat menjadi masalah diagnostik sehari-harinya. Sebelumnya, biopsi eksisi merupakan pilihan dalam memastikan benjolan tersebut, Saat ini dengan berkembangnya radioimaging, maka kombinasi dengan biopsi aspirasi jarum halus (BAJH) memungkinkan untuk mengurangi eksisi bedah yang tidak perlu pada lesi jinak. ${ }^{3}$ Pemeriksaan BAJH dan radioimaging (mammografi, USG) melengkapi pemeriksaan fisik merupakan Triple Diagnostic untuk nodul payudara. $^{3}$

Pemeriksaan patologi merupakan standar emas untuk diagnosis kanker termasuk mengetahui etiologi, patogenesis, korelasi kninikopatologis dan penentuan prognostik. Pesatnya kemajuan tehnologi dan disadarinya bahwa kanker payudara merupakan penyakit yang heterogen telah menggeser fokus prognostik dengan penekanan pada identifikasi morfologi 
dan penanda imunohistokimia (IHK) yang relevan ${ }^{4}$

Pengambilan sampel yang umum digunakan untuk diagnosis lesi payudara dapat dilakukan preoperatif, intraoperatif dan postoperatif. Diagnosis patologi preoperatif dapat ditegakkan melalui pemeriksaan BAJH, core needle biopsy (CNB) dan open surgical biopsy. Diagnosis intraoperatif dilakukan melalui pemeriksaan potong beku (frozen section) sedangkan diagnosis postoperatif didapat melalui eksisi, lumpektomi ataupun mastektomi.

Berdasarkan pengolahan sampel, maka pemeriksaan patologi untuk lesi payudara ini dibagi atas pemeriksaan berbasiskan sel (sitopatologi) pada sampel BAJH, imprint, dan sekresi payudara serta pemeriksaan berbasiskan jaringan (histopatologi) pada sampel CNB, open surgical biopsy, insisi, eksisi, lumpektomi dan mastektomi.

\section{II.1 Diagnosis Patologi Preoperatif}

Diagnosis preoperatif memberikan beberapa keuntungan sebagai berikut :

- Diagnosis segera akan menghemat waktu dan mengurangi kecemasan pasien

- Terapi defenitif dapat direncanakan lebih lanjut dengan persetujuan pasien

- Jika terdiagnosis kanker, maka pemeriksaan untuk mengetahui stadium dapat dilakukan preoperatif

- Banyak lesi jinak yang dapat didiagnosis secara tepat melalui $\mathrm{BAJH}$ dan radioimaging sehingga pembedahan dapat dihindari

- Fasilitas rumah sakit dapat dipergunakan lebih ekonomis karena luasnya operasi telah diketahui dari awal

- Kebutuhan pemeriksaan potong beku berkurang ${ }^{3}$

Pengambilan sampel preoperatif biasanya melalui BAJH, CNB dan open surgical biopsy. Dibanding yang terakhir, maka BAJH dan CNB lebih kurang invasif. Pada lesi yang palpable, jarum biopsi dapat dituntun oleh palpasi sedangkan pada lesi dengan abnormalitas mammografi yang nonpalpable maka penempatan jarum dengan tuntunan imaging. ${ }^{1}$ Pemilihan metode mana yang akan digunakan tergantung kepada ketersediaan layanan, karakteristik lesi mencakup ukuran, lokasi, dan konsistensi, performan diagnostik, preferensi dokter dan status ekonomi pasien. ${ }^{1}$

\section{II.1.1 BAJH (Biopsi Aspirasi Jarum Halus)}

Pemeriksaan BAJH menggunakan jarum halus untuk mengekstrak sel ataupun cairan dari area yang abnormal. Pemeriksaan ini telah diterima di seluruh dunia dan terbukti aman, sederhana, cepat dan efektif dari segi biaya jika dilakukan secara tepat pada layanan sitopatologi yang berkualitas. Sejumlah penelitian menunjukkan bahwa BAJH memiliki sensitifitas dan spesifisitas relatif tinggi dalam menilai lesi payudara. 1

Pada lesi payudara yang palpable maka BAJH sebaiknya di dahului oleh pemeriksaan mammografi ataupun USG sehingga dapat menentukan area biopsi secara lebih tepat. Disamping itu, jika BAJH dilakukan terlebih dahulu maka ada perdarahan post biopsi tersebut 
dapat menggangu interpretasi radioimaging. ${ }^{3}$

Pemeriksaan BAJH untuk lesi payudara merupakan metode yang reliabel, akurat dan hemat dari segi biaya. Keunggulan utama dari BAJH adalah sebagai berikut :

- BAJH dapat menggantikan open biopsy dan potong beku terutama pada lesi jinak. BAJH merupakan tehnik yang sederhana yang dapat dilakukan di pada unit rawat jalan tanpa anestesi

- Metode cepat dan waktu proses sampel yang cepat. Patolog dapat menilai adekuasi spesimen sementara pasien masih di ruangan BAJH. Kecepatan diagnosis sangat penting dan ini sangat bermakna untuk dokter klinis dan pasien

- BAJH memberikan diagnosis sebelum pembedahan sehingga memberikan kesempatan kepada ahli bedah untuk merencanakan follow up ataupun tatalaksana selanjutnya.

- BAJH sangat membantu dalam mengenali lesi yang kecil dan fleksibel hampir tanpa komplikasi

- BAJH merupakan prosedur berbiaya rendah dengan sensitifitas yang masih dapat dipertahankan. ${ }^{5}$

Namun begitu, BAJH juga memiliki keterbatasan yaitu :

- Tehnik ini memerlukan patolog yang terlatih dan berpengalaman. Sitopatolog yang berpengalaman memiliki sensitifitas dan spesifisitas yang lebih tinggi

- Pasien ataupun ahli bedah memiliki ekspektasi yang tinggi terhadap
BAJH yang tidak selalu dapat dipenuhi.

- Lesi proliferatif dengan atipia minimal yang kurang memberikan gambaran defenitif keganasan tidak dapat diklasifikasikan dan memerlukan pemeriksaaan lanjutan dengan pemeriksaan berbasis jaringan (CNB, open biopsy)

- Sangat sulit untuk memastikan lesi ganas sebagai insitu atau invasif, padahal pembedaan ini sangat penting untuk penatalaksanaan pasien

- BAJH merupakan pemeriksaan sitologi yang tentunya berbeda dengan pemeriksaan berbasis jaringan (histopatologi). Sampel BAJH sulit untuk dilakukan pemeriksaan imunohistokimia ataupun pemeriksaan molekular karena keterbatasan jumlah sampel yang ada. ${ }^{5}$

Selain itu, BAJH punya keterbatasan intrinsik dikarenakan kurangnya arsitektur histologik. Kesulitan diagnostik dapat ditemukan pada beberapa lesi bahkan oleh seorang sitopatolog yang berpengalaman sekalipun. ${ }^{1}$

Indikasi pemeriksaan BAJH pada lesi payudara adalah sebagai berikut :

- Diagnosis kista sederhana

- Pemeriksaan dugaan rekuren pada kasus yang sebelumnya telah terdiagnosis kanker

- Konfirmasi kanker yang lanjut dan inoperable

- Konfirmasi preoperatif dari kasus yang secara klinis diduga kanker

- Penilaian setiap benjolan yang jinak 
atau ganas secara klinis, sehingga dapat ditentukan tatalaksana klinis

- Pelengkap mamografi pada skrining lesi payudara

- Untuk mendapatkan sel tumor untuk analisis khusus dan penelitian seperti penelitian reseptor hormon, analisis DNA, imunohistokimia, kinetik sel dan penelitian molekuler. ${ }^{3}$

Pelaporan interpretasi BAJH dapat dengan menggunakan kategori umum. Pencantuman diagnosis spesifik sangat dianjurkan. Kategori umum pelaporan BAJH adalah sebagai berikut :

a. Negatif untuk sel ganas

b. Atypical

c. Suspicious

d. Positif untuk sel ganas

e. Non diagnostik (inadekuat atau tidak memuaskan). 6

Dokter klinis hendaknya selalu mengkorelasikan pelaporan BAJH dengan temuan klinis dan mammogafi atau USG (triple diagnostic) untuk mengurangi risiko keganasan yang tidak terdiagnosis. ${ }^{6}$

BAJH memiliki reliabilitas tinggi dalam mendiagnosis kanker jika sampel adekuat dan sitopatolog yang berpengalaman, . Jika hasil interpretasi BAJH adalah "atypical" atau "suspicious" maka prosedur BAJH sebaiknya diulangi atau lesi dieksisi untuk pemeriksaan histopatologi. ${ }^{2}$ Hal ini tidak dapat dihindari oleh karena adanya gambaran sitologi jinak dan ganas yang tumpang tindih. ${ }^{6}$ Dengan pemeriksaan BAJH saja tidak mungkin untuk membedakan karsinoma in situ dengan karsinoma invasif . ${ }^{7}$

Jika hasil interpretasi BAJH negatif sel ganas namun masih terdapat keraguan apakah sampel sudah akuat atau telah diinterpretasi secara benar, maka triple diagnostic dapat membantu. ${ }^{2}$ Negatif palsu dapat dikurangi dengan triple diagnostic tersebut. ${ }^{6}$

Sensitifitas BAJH dalam mendiagnosis kanker payudara adalah 90-95\% dari banyak penelitian. ${ }^{3}$ Dari penelitian di Thiland yang melibatkan 2375 lesi payudara, memperlihatkan sensitifitas $84,4 \%$, spesifisitas $99,5 \%$, nilai prediksi positif $99,8 \%$, nilai prediksi negatif $84,3 \%$ dan akurasi diagnostik keseluruhan $91,3 \% .1$

Komplikasi dari BAJH adalah sangat jarang dan yang paling umum adalah nyeri dan perdarahan. ${ }^{1} \mathrm{Hal}$ ini dapat diminimalkan dengan menggunakan jarum yang lebih kecil dan memberikan tekanan setelah jarum di lepaskan dari lesi. Komplikasi lain yang mungkin terjadi adalah reaksi vasovagal, infeksi, dan pneumothorak, infark, penyebaran sel malignant melalui needle track yang sangat jarang terjadi dan itu biasanya pada pemakaian jarum yang besar . ${ }^{1}$

\section{II.1.2 Core Needle Biopsy (CNB)}

Untuk mengatasi keterbatasan BAJH maka pada banyak negara maju menggantinya dengan prosedur diagnostik berbasiskan jaringan seperti halnya CNB. Jaringan yang didapat dari prosedur CNB memungkinkan untuk pemeriksaaan histologik. Dengan CNB diagnosis defenitif pada beberapa lesi lebih dapat ditegakkan dibandingkan dengan $\mathrm{BAJH}$, serta memungkinkan juga untuk pemeriksaan penanda tumor seperti halnya spesimen yang didapat dari pembedahan. Meskipun dibandingkan BAJH, CNB lebih invasif, memakan waktu lebih lama dan lebih mahal namun CNB lebih kurang invasif, relatif hemat biaya, lebih mudah dilakukan dengan parut yang minimal 
dibandingkan dengan open surgical biopsy. ${ }^{1}$

Tindakan CNB bisa menjadi pilihan diagnostik lini kedua untuk lesi dimana pemeriksaan BAJH gagal untuk mendapatkan diagnosis yang akurat. Core needle biopsy dianjurkan pada diagnostik untuk membedakan karsinoma insitu dengan karsinoma invasif, atau diperlukannya penentuan subtipe tumor. Hal ini biasanya pada kasus yang baru teridentifikasi secara klinis atau radiologis sebagai karsinoma primer payudara terutama pada pasien yang menjadi kandidat untuk diberikan kemoterapi adjuvan. ${ }^{1}$

Pelaporan patologi untuk sampel dari CNB secara umum sebagai berikut :

a. Jaringan normal

b. Jinak, lesi jinak yang spesifik seperti fibroadenoma, fat necrosis, fibrocystic change

c. Jinak, namun kemaknaan belum dapat ditentukan (uncertain significance) - lesi diketahui berasosiasi dengan keganasan didekatnya atau heterogen termasuk proliferasi epitel atipik, radial scar, lesi papillary, lesi fibroepitelial yang selular

d. Mencurigakan, secara histologi mencurigakan untuk keganasan namun belum memenuhi kriteria keganasan yang defenitif

e. Ganas, karsinoma insitu, karsinoma invasif ataupun keganasan lainnya. ${ }^{5}$

Namun harus diketahui bahwa, terlewatkannya diagnosis karsinoma pada sampel NCB dapat dipengaruhi oleh tipe alat biopsi yang digunakan, jumlah core yang didapat, kaliber needle yang dipakai dan persentase lesi yang diambil. $^{7}$

Sampel NCB dapat ditentukan derajat histologiknya dengan $70 \%$ kesesuaian dengan derajat yang dibuat dari sampel pembedahan. Penentuan tipe dapat dilakukan pada sampel BAJH dan NCB, namun bisa jadi belum defenitif karena adanya tumor dengan tipe campuran. Pemeriksaan status reseptor hormon dan HER2 dapat dilakukan pada sampel NCB dengan kesesuaian sekitar $98-99 \%{ }^{7}$

\section{II.2 Diagnosis Patologi Intraoperatif}

Persentase spesimen payudara yang diperiksa dengan potong beku intraoperatif mulai berkurang akhir-akhir ini sejalan dengan modalitas diagnostik baru yang berkembang mengubah tatalaksana dari lesi payudara. Selain itu sebagian besar lesi ganas payudara telah didiagnosis sebelum terapi bedah defenitif (lumpektomi, mastektomi) baik dengan pemeriksaaan BAJH ataupun CNB. ${ }^{8}$

Indikasi pemeriksaan potong beku adalah untuk menetapkan diagnosis dari lesi payudara sebelum dilakukan terapi defenitif serta untuk mengevaluasi margin reseksi. ${ }^{8}$ Pendekatan sederhana terhadap lesi yang berbeda yang diterima pada potong beku spesimen payudara dikelompokkan dalam subgrup diagnostik berikut :

a. Lesi jinak menyerupai kanker, contoh : radial scar, sclerosing adenosis dan sclerosing papilloma

b. Lesi fibroepitelial, contoh : fibroadenoma, phyllodes tumor

c. Karsinoma invasif

d. Deferred diagnosis (diagnosis ditangguhkan) ${ }^{8}$ 
Terdapat beberapa kondisi dimana diagnosis spesifik tidak dapat ditegakkan pada potong beku. Seluruh lesi proliferasi epitel, lesi epithelial papillari sebaiknya tidak didiagnosis dengan potong beku intraoperatif. Lesi limfoproliferatif didiagnosis akhir berdasarkan morfologi dan flow cytometri sedangkan tumor jaringan lunak sebaiknya juga ditangguhkan diagnosis intraoperatifnya. ${ }^{8}$

Pemeriksaan sitologi intraoperatif juga dapat dilakukan bersamaan dengan potong beku untuk melengkapi analisis tumor. Tehnik ini dapat mengatasi kesulitan analisis pemeriksaan morfologi akibat artifak yang terjadi. Hapusan sitologi dapat dilaukan dengan tiga cara yaitu : sitologi imprint, squash preparation dan scrape preparation. ${ }^{8}$

\section{II.3 Diagnosis Patologi Postoperatif}

Diagnosis postoperatif ditegakkan berdasarkan sampel yang didapat dari eksisi pembedahan tumor payudara. Pemeriksaan morfologi masih merupakan dasar dalam penentuan diagnosis terutama kasus neoplastik payudara. Melalui pemeriksaan makroskopik dan mikroskopik, patolog juga dapat menentukan etiologi, memperkirakan perangai tumor, memberikan korelasi dengan tampilan klinis. $^{4}$

Dengan berkembangnya tehnik molekular saat ini maka pemeriksaan patologi telah mengalami perubahan dan perluasan. Patologi tidak lagi hanya menegakkan diagnosis, namun dapat membantu klinisi dalam menilai prognosis serta prediktif terhadap terapi kanker payudara yang berkembang saat ini.

Saat ini patologi memainkan
peranannya dalam menegakkan
diagnosis dan ditambah dengan
mengidentifikasi respon penanda tumor
terhadap manipulasi terapeutik sehingga
seorang patolog tidak dapat terlepas
dalam hal tatalaksana pasien. ${ }^{4}$

Secara tradisional, patolog melalukan pemeriksaan makroskopik dan mikroskopik dari spesimen eksisi yang diterima. Secara makroskopik penilaian dilakukan terhadap integritas spesimen, ukuran spesimen, ukuran tumor, focalitas tumor, perluasan tumor secara makroskopik, dan jumlah kelenjar limfe yang diperiksa. ${ }^{9}$

Penilaian mikroskopik meliputi ada tidaknya karsinoma duktal insitu yang mencakup ukuran, pola arsitektural, derajat inti sel, necrosis dari karsinoma in situ tersebut, ada tidaknya karsinoma lobular insitu, tipe histologi karsinoma invasif, derajat histologi menurut skor histologik Nottingham, margin, invasi lymphvascular, mikro dan makrometastasis pada kelenjar limfe, perluasan ekstranodal, dan stadium patologik (pTNM). ${ }^{9}$ Sebagian besar informasi prognostik yang dibutuhkan untuk pengambilan keputusan tatalaksana terhadap lesi payudara didasarkan kepada pemeriksaan patologi. ${ }^{5}$ Data subtipe histopatologi, derajat, ukuran, invasi vaskular dan status kelenjar limfe memberikan informasi mengenai kemungkinan luaran pasien dan kebutuhan terapi adjuvan. ${ }^{7}$

Selain pemeriksaan mikroskopik rutin dengan pulasan hematoxilin eosin, terdapat juga pemeriksaan tambahan berupa pemeriksaan molekular biomarker yang dapat berperan diagnostik, prognostik dan prediktif. Umumnya pemeriksaan biomarker 
tersebut dilakukan dengan metode imunohistokimia.

Untuk kanker payudara terdapat tiga biomarker molekular yaitu estrogen receptor (ER), progesteron receptor (PR) dan HER2 yang diadopsi sebagai pemeriksaan rutin dari kanker payudara untuk menentukan prognosis dan prediktif tumor. ${ }^{5}$ Berdasarkan ekspresi dari ketiga penanda tersebut maka kanker payudara di subklasifikasikan kedalam beberapa subtipe molekular yang masing-masingnya berhubungan dengan gambaran klinis, respon terapi dan luaran pasien. Ketiga penanda molekular tersebut merupakan target dan atau indikator dari efektifitas terapi pada kanker payudara invasif sehingga harus diperiksa secara akurat. ${ }^{7}$ Selain itu juga terdapat biomarker lainnya seperti Ki-67, EGFR, basal cytokeratins, and p53 yang juga biasa diapakai untuk kasus kanker payudara. ${ }^{5}$

Kanker payudara merupakan penyakit heterogen dengan banyak subtipe, variasi ukuran, derajat, potensi metastasis, dan juga variasi prognosis. Dengan demikian pilihan terapi ditentukan oleh informasi yang didapat dari pemeriksaan patologi. ${ }^{7}$

\section{Penutup}

Pemeriksaan patologi berfokus pada diagnosis, patogenesis, prognosis dan korelasi klinikopatologi. Secara tradisional pemeriksaan patologi berupa pemeriksaan makroskopik, mikroskopik melalui sitopatologi dan histopatologi memberikan informasi diagnosis dan prognosis. Pemeriksaan tambahan berupa analisis imunohistokimia dari tiga penanda molekular ER, PR, dan HER2 yang telah menjadi pemeriksaan rutin berfungsi sebagai penanda prognostik dan prediktif dari kanker payudara. Kemajuan dalam tehnik pemeriksaan molekular telah membuka eksplorasi baru kedalam patogenesis kanker, dan berpotensi untuk pengembangan terapi baru dan upaya preventif. Hal ini juga membuka peranan baru patologi dalam prognostik dan tatalaksana kanker payudara. ${ }^{4}$

\section{Daftar Pustaka}

1. Gong Y. 2013. Breast cancer : Pathology, Cytology, and Core Needle Biopsy Methods for Diagnosis in Breast and Gynaecologicial Cancer ; An Integrated Approach for Screening and Early Diagnosis in Developing Countries. Springer Science+Business Media. New York

2. Koss LG, Melamed MR. 2006. The Breast in Koss' Diagnostic Cytology and It's Histopathologic Bases. $5^{\text {th }}$ ed. Lippincot Williams \& Wilkin. Philadeplhia, Baltimore, New York

3. Orell SR, Sterrett GF, Whtaker D, Lindholm. 2005. The Breast in Fine Needler Aspiration Cytology. $4^{\text {th }}$ ed. Elsevier Churchill Livingstone

4. Leong ASY, Zhuang Z. 2011. The Changing Role of Pathology in Breast Cancer Diagnosis and Treatment. Pathobiology Jun 78(2)

5. Malley FPO, Pinder SE, Mulligan AM. Editor Goldblum JR. Breast Pathology. A Volume in the Series Foundation in Diagnostic Pathology. $2^{\text {nd }}$ ed. Elsevier

6. Ducatman BS, Wang HH. 2009. Breast in Cytology Diagnostic Principles and Clinical Correlates. $3^{\text {rd }}$ ed. Saunders Elsevier. Philadelphia

7. Lakhani SR, Ellis IO, Schnitt SJ, Tan $\mathrm{PH}$, Vijver MJvd. 2012. WHO Classification of Tumours of The Breast. 
$4^{\text {th }}$ ed. International Agency for Research on Cancer. Lyon

8. Laucirica R. 2005. Intraoperative Assessment of the Breast Guideline and Potential Pitfall. Arch Pathol Lab Med. Vol 129

9. Lester SC, Bose S, Chen $Y Y$, Connolly JL, Baca ME, Fitzgibbon PL et al. 2009. Protocol for the Examination of Specimen From Patients With Invasive Carcinoma of the Breast. Arch Pathol Lab Med. Vol 133 